\title{
高原子番号ガスを用いたレーザープラズマ加速による電子ビーム制御
}

\author{
森 道昭 \\ 日本原子力研究開発機構 量子ビーム応用研究部門 次世代レーザー開発研究グループ (
}

\section{Control of Electron Beam by Using High-Z Gas Target in the Laser-Plasma Acceleration}

\author{
Michiaki MORI \\ Japan Atomic Energy Agency, 8-1-7 Umemidai, Kizugawa, Kyoto 619-0215
}

(Received July 11, 2012)

\begin{abstract}
We investigate the pointing stability and the divergence of a quasi-monoenergetic electron beam generated in a self-injected laser-plasma acceleration regime using high-Z gas-jet target. Gas-jet targets have been irradiated with focused $40 \mathrm{fs}$ laser pulses at the 4-TW peak power. A pointing stability and a beam divergence of electron beam were improved using argon target. These values were about three times smaller than at the optimum condition using helium. This stabilization method is available for another gas material such as nitrogen. At nitrogen gas-jet target, the pointing stability is more improved to two times smaller than that in argon gas-jet target and the peak energy is increased to $>30 \mathrm{MeV}$. These results prove that this method not only stabilizes the e-beam but also allows controlling the electron energy.
\end{abstract}

Key Words: Laser-plasma electron accelerator, Ionization stage control, Relativistic laser plasma acceleration

1. はじめに

レーザー駆動電子ビームをさまざまな応用に展開して いく上で電子ビームの制御・安定性向上は重要な課題で あり，2つのレーザー光の衝突による定在波を用いる方 法 $^{1-5)}$ や, 磁化プラズマを用いる方法 ${ }^{6,7)}$, プラズマ密度 の急勾配を用いる方法 ${ }^{8.9)}$, さらにコントラストを向上 する方法 ${ }^{10-12)}$ など様々な方法が提案・実証されている. 高強度レーザーと気体との相互作用を用いたエネルギー 幅の狭いいわゆる準単色構造を持つ電子ビームの発生研 究では, Ref. 13などのごく一部の研究を除いて通常レー ザー光の照射で容易に完全電離となる水素やへリウムと いった低い原子番号 (Low-Z)のガスが用いられる。これ は，完全電離となるためプラズマ密度の評価が容易であ ること, また準単色構造の電子ビームが共鳴的に出現す るプラズマ密度が $10^{19} \mathrm{~cm}^{-3}$ 近辺であることからパルスガ スジェットで比較的容易に生成することができるためで ある. しかし，近年の研究で高い原子番号のガス (High-Z)が制御性向上に有用であることが分かってき $た^{14-19)}$ 。本稿においては新しい制御手法の一つである High-Zガスを用いたレーザープラズマ加速による電子 ビームの制御に関し, 関連する研究の最近の動向を含め て実験結果を中心に解説する。
2. Ionization injection

フェムト秒テラワットレーザー光を集光させる事で得 られる非常に高いレーザー電場は, 原子核に束縛される 電子の軌道を歪ませ，レーザー周期の時間スケールでの 電離をもたらすことができる20-22)。これがトンネル電離 の概念であり, 多光子電離と併せてフェムト秒レーザー と物質との相互作用を考える上で基本的な電離過程とし て知られている。一方，レーザーによってプラズマ波を 励起し, 高エネルギー電子を発生させるレーザープラズ マ電子加速 ${ }^{23)}$, 特にレーザーウェーク場加速では, 通常 テラワット級チタンサファイアレーザーと組み合わせる 形で，前述のようにその照射で十分に完全電離となる水 素やへリウムなどの低原子番号 (Low-Z)のガスが用いら れている。しかし，高原子番号 (High-Z)のガスでは，例 えばアルゴンの場合, 内殼のイオン化ポテンシャルが数 百 $\mathrm{eV}$ 超えるため, レーザー電場でもたらされる電子 のquiver運動のエネルギーが電子の静止エネルギーに匹

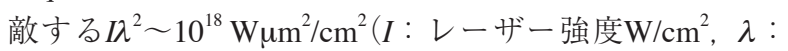
レーザー波長 $\mu \mathrm{m})$ のいわゆる相対論的なレーザー強度で もその電離は不完全となる。 その一方で, 第1イオン化 ポテンシャルは, 例えばへリウムとアルゴンでは, $E_{\mathrm{i}, \mathrm{He}}=24.6 \mathrm{eV}, E_{\mathrm{i}, \mathrm{Ar}}=15.7 \mathrm{eV}$ のように, 逆に低くなる. この違いによって, トンネル電離や後ほど取り上げるカ 
スケード電離を問わず電離の時間スケールや発展などの 違いとして表れ，Low-Zとは異なるウェーク場の形成や 電子加速の振る舞いをする。2007年にOzらはRF加速器 から発生する超高エネルギーの電子バンチを使ったプラ ズマウェーク場による電子ビームの発生実験を行い, Li プラズマがHeプラズマに閉じ込められる特殊な状態を 生成させ， $28.5 \mathrm{GeV}$ のエネルギーの電子ビームの照射に よって, $7.6 \mathrm{GeV}$ のネルギー利得が得られることを明 らかにした(ionization injection) ${ }^{24)}$. この加速では, Heお よびLiがバックグランドのプラズマ源を供給し，第1イ オン化ポテンシャルの低い $\left(E_{\mathrm{i}, \mathrm{Li}} \sim 5 \mathrm{eV}\right) \mathrm{Li}$ の電子が ウェーク場を保持する形で大振幅のウェーク場を形成さ せ, これに第1イオン化ポテンシャルの高い $\left(E_{\mathrm{i}, \mathrm{He}} \sim\right.$ $25 \mathrm{eV}) \mathrm{He}$ の電子を加速するというものであった。つま り, Liから放出される自由電子と Heから放出される自 由電子それぞれが加速媒体となる電子と被加速電子の供 給源を担うという形で効率的な加速を供するというもの であった，この研究では，電子加速の実証のみでそれが 有する制御性については言及されていなかった。その 後, PakらのグループとMcGuffeyらのグループはこの原 理をレーザープラズマ電子加速に展開し2010年にヘリウ ムと窒素の混合ガスを用いて100 TW級レーザー励起に よる加速実験で $100 \mathrm{MeV}$ 級の電子加速 ${ }^{15,16}$ を実証し，さ らにその後の研究ではLiuらのグループもこの制御法の 実証に加わる形で2ステージ加速による数百 $\mathrm{MeV}$ 級の電 子ビーム発生に至っている ${ }^{17,18)}$. 特にPakらの研究 ${ }^{15)}$ は, Ozらの研究でイオン化エネルギーの差異を第1イオン化 の異なる別々のガスで行っていたものをHigh-Zガスの外 殼 (L殼) と内殼 $(\mathrm{K}$ 殼)のイオン化の大きなギャップを利 用する事で同等の効果が得られることを明らかにすると ともに，このような内殼の電離が非常に高いレーザー強 度を必要とすることから, レーザースポットのごく一部 の領域でしか電子加速が発生しないため, 非常に品質の 高いエネルギーのそろった電子ビームが発生できる事も 明らかにしている。

\section{Ionization-stage control}

さて，テラワットレーザー装置から発生するレーザー パルスはテラワットのメインパルス以外にもレーザー光 増幅の過程で副次的に生じるASE (Amplified Spontaneous Emission)ペデスタルと呼ばれる, メインピークに比べ て通常5〜7桁程度低いピコからナノ秒の比較的長い時間 の背景光 (ペデスタル)を持つ.この抑制が不十分な場 合, メインパルス到達前にターゲットが加熱されプラズ マ化(プレプラズマ)した状態でメインパルスと相互作用 する。レーザー駆動イオン加速として典型的なシース電 場加速 (Target Normal Sheath Acceleration) ${ }^{25-27)}$ では, 高い エネルギーのイオンビームを発生させるため数ミクロン 以下の膜厚の固体薄膜をターゲットに用いた研究が展開 している，そのメカニズムは高強度短パルスレーザー光 を薄膜に照射することで高速電子を発生させ, その高速 電子で生じる高々数 $\mu \mathrm{m}$ の加速長の静止した電場で高エ
ネルギーイオンを発生するものである。この加速を効率 よく行うためにはターゲットの薄膜化とターゲット毫面 の高密度状態の両立が重要である。したがって,この ターゲット董面で生じる加速場を安定的に形成させる (Fig. 1 (a))ため, 高速ポッケルスセルの導入 ${ }^{28)}$ やプラズ マミラー ${ }^{29)}$ など，プレパルスの抑制に主眼が置かれてい る。これに対し，プラズマ波(ウェーク場)を加速媒体と したレーザープラズマ電子加速は，Fig. 1 (b)に示すよ うに数百 $\mu \mathrm{m}$ を超える比較的長距離にわたるスケールで 光速に近い位相速度を持つプラズマ波によって加速が行 われる。そのため, ペデスタルの抑制による電子ビーム の安定化の方法 ${ }^{10-12)}$ 以外にも，磁化プラズマを用いた制 御の方法 ${ }^{6)}$ や本方法 ${ }^{14)}$ のように逆に積極的な制御の道具 として利用するなど多様化している。 ここで磁化プラズ マを用いた制御の手法について少し補足する。この手法 は，ターゲット近傍にレーザーの伝播方向と同軸の均一 磁場を与え，プレパルス照射によって磁化プラズマを生 成させ，それを電子ビームの制御に用いるというもので ある。ここで生成される磁化プラズマは, サイクロトロ ン運動で集光点付近でピンチをする予備加速電子の供給 も兼ねたテーパー構造のプラズマ導波路(プラズママイ クロオプティクス)を形成する。このプラズマ導波路に メインパルスを入射させることで，(狭い導波路のため) レーザー強度の増加がもたらされる結果, 密度勾配によ る制御 ${ }^{8,9)}$ に類似する局所的な非線形のウェーク場が励 起され効率的で且つ指向性・位置安定性に優れる電子 ビームを得るというものである

さて，前述のプレプラズマに話を戻す。このプレプラ ズマの形成において支配的な電離過程は多光子電離とそ れに続くカスケード電離である ${ }^{30,31)}$ 。このカスケード電 離とは, 多光子電離によって生じた自由電子が逆制動放 射で加速され, さらに他の原子と衝突して電離をもたら し，なだれ的に電離が進展するものである。したがっ て，プレパルスを含むレーザーパルスの時間プロファイ ルは, 当然電離度やプラズマ温度, また電子密度の空間 分布に変化を与え, 結果的に発生する電子ビームに影響 を及ぼす。一方，前述のようにHigh-ZガスはLow-Zガス と比較して低い第1イオン化しきい值を持っているため, より低いレーザー強度で電離が可能である. Ionizationstage controlはプレパルス（強度・パルス幅）を制御し,

(a)

(b)

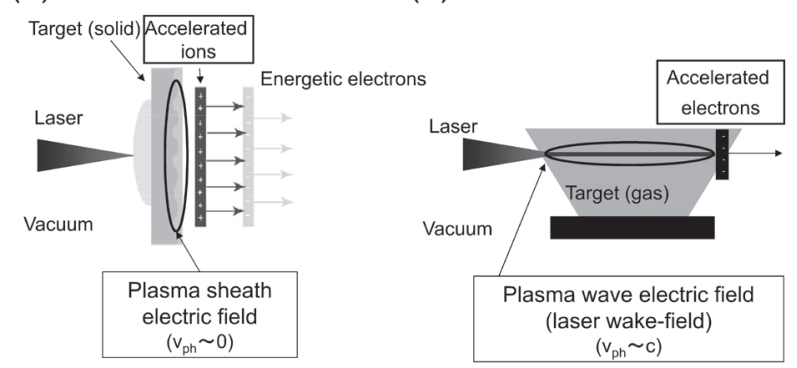

Fig. 1 Image of ion acceleration by plasma sheath electric field (a) and electron acceleration by plasma wave electric field (b). Here, $v_{\mathrm{ph}}$ is phase velocity of the acceleration field. 
カスケード電離のしきい值近辺に設定させることによ り，比較的低温のプラズマの膨張を利用して加速場の長 尺化をもたらすレーザー光導波路を生成させ，電子ビー 厶の安定化を行うものである。このレーザー光導波路 は, 中心部で低く周囲で高いプラズマ電子密度分布を形 成させることで，屈折率に勾配を持つグレーデッドイン デックス型光ファイバと同等の構造を持ち, メインレー ザーパルスはこの導波路を加速媒体となるウェーク場を 形成しながら長尺に伝搬するため ${ }^{32)}$, 結果的に電子ビー ムは長い加速長によって横方向の運動に空間的な制約を 与えられる。したがって, 位置安定性が高く, 発散角の 小さな制御された電子ビームを得る。これがIonizationstage controlの原理的な概念である。

具体的に実験例を示す形で解説をすすめる。実験セッ トアップをFig. 2に示す. これは, ピーク出力4 TWの フェムト秒チタンサファイアレーザーを励起レーザーと して使い, Low-Zガスとしてへリウム, High-Zガスとし てアルゴンで発生する電子ビームおよび形成される ウェーク場の比較を行った。ここでレーザーのプレパル スのピークパワー，パルス幅はそれぞれ $10 \mathrm{MW}$, $500 \mathrm{ps}$, メインパルスのピークパワー, パルス幅はそれ ぞれ4 TW, $40 \mathrm{fs}$ (full-width-half-maximum: FWHM) でF=22 の軸外し放物面鏡 (Off-Axis-Parabola mirror: OAP) で約 $20 \mu \mathrm{m}(\mathrm{FWHM})$ のスポット径で集光させた。これはレー ザー光強度でそれぞれ $2 \times 10^{12} \mathrm{~W} / \mathrm{cm}^{2}, 9 \times 10^{17} \mathrm{~W} / \mathrm{cm}^{2}$ とな る. ターゲットガスは集光点近傍に設置したパルスガス ジェットを通じて供給し, それ以外の領域はプラズマに よるレーザー光の発散 (defocus) を防ぐために真空状態 $\left(<10^{-2} \mathrm{~Pa}\right)$ である。このパルスガスジェットはレーザー 光のレーリー長 (約 $1.3 \mathrm{~mm}$ )の3倍近い3.5 mm(FWHM)の スケール長のフラットトップな密度プロファイルが生じ るように設計している。 ここで, 供給するターゲットガ スの集光点近傍での中性ガス密度は, ヘリウム, アルゴ ンでそれぞれ2.2 × $10^{19} \mathrm{~cm}^{-3}, 5.0 \times 10^{18} \mathrm{~cm}^{-3} に$ 設定し た.これは, $9 \times 10^{17} \mathrm{~W} / \mathrm{cm}^{2}$ のメインパルスのピーク強 度でのトンネル電離をシンプルに解釈したBSI (Barrier Suppression Ionization) モデル ${ }^{22)} に よ る$ 電離の価数の考察

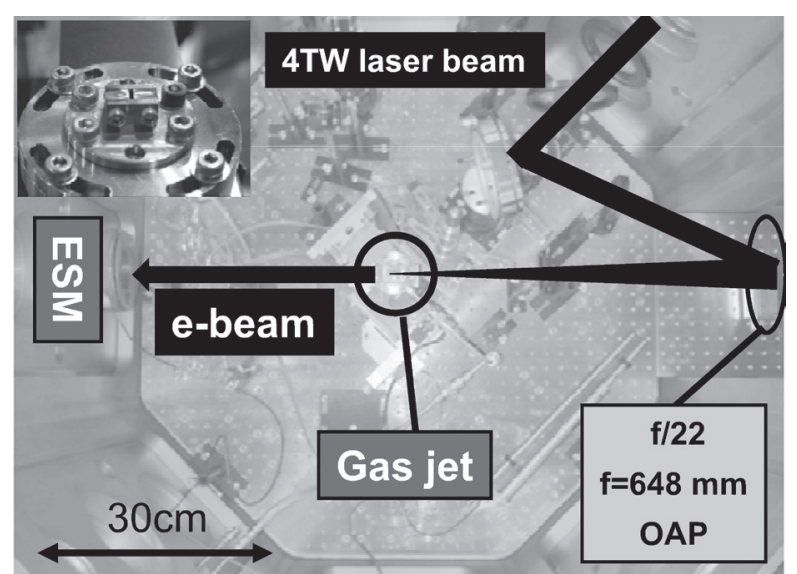

Fig. 2 Experimental setup for energetic electron generation using terawatt laser. The inset shows typical gas-jet nozzle.
を反映すると双方ともほぼ4.5 $\times 10^{19} \mathrm{~cm}^{-3}$ に相当する. 一方，プレパルス $\left(\right.$ 強度 $\left.2 \times 10^{12} \mathrm{~W} / \mathrm{cm}^{2}\right)$ によるカスケー ド電離のしきい值 ${ }^{31)}$ はへリウムおよびアルゴンでそれぞ れ4 $\times 10^{12} \mathrm{~W} / \mathrm{cm}^{2}$ および $9 \times 10^{11} \mathrm{~W} / \mathrm{cm}^{2}$ と見达まれるため, レーザー光導波路の形成はアルゴンにおいてのみ生じ る。このプレプラズマのプラズマ温度はレーザー強度が 電離しきい值に非常に近い事もあり，この領域でのプラ ズマ加熱で支配的となる逆制動放射を考慮しても電離ポ テンシャルの2倍程度 $(\sim 30 \mathrm{eV})$ の比較的低温状態にとど

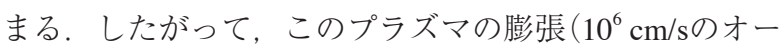
ダーの速度) と時間スケール (カスケード電離に必要な時 間から推測して200 ps 程度) から，レーザー光の横断面 方向に非常に浅い(高々 $10 \%$ 程度) 密度変調を持ったくぼ み状のプレプラズマの形成が推測される。この構造は非 常に浅いものの，レーザー光導波路の条件 ${ }^{32}$ を十分に満 たすため, レーザー光はこの形成された導波路を通じて 中心部に効率的にガイドされ，その結果前述の磁化プラ ズマを用いた電子ビームの制御と同様に電子ビームの制 御性・品質向上がもたらされる。

実際に実験から得られた電子ビーム放射方向の安定性 の計測結果をFig. 3に示す。これは，電子ビームの空間 イメージの計測可能な電子スペクトロメーター (Electron Spectrum Meter: ESM ・電磁石(空間イメージ撮像の際は 残留磁場をキャンセルするよう電磁石に微弱な逆方向電 流を与え磁場をゼロにして計測），アルミニウム製エネ

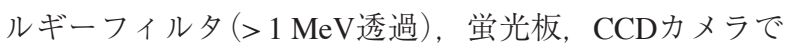
構成)にて撮像したものを，ヘリウム，アルゴンそれぞ れ50 shot分プロットしたものである。電子ビームの位置 安定性が4倍以上 $(9.8 \mathrm{mrad}(\mathrm{rms}) \rightarrow 2.4 \mathrm{mrad}(\mathrm{rms}))$ 改善し ていることを示している。また，ビーム発散角において も1/3に抑制 $(29.8 \pm 8.8 \mathrm{mrad}(\mathrm{FWHM}) \rightarrow 10.8 \pm 2.4 \mathrm{mrad}$ (FWHM))されている事も確認している(Fig. 4). その一 方，生成されているウェーク場の長さについてもその長 尺化を観測した。ウェーク場の長さは，励起レーザーが

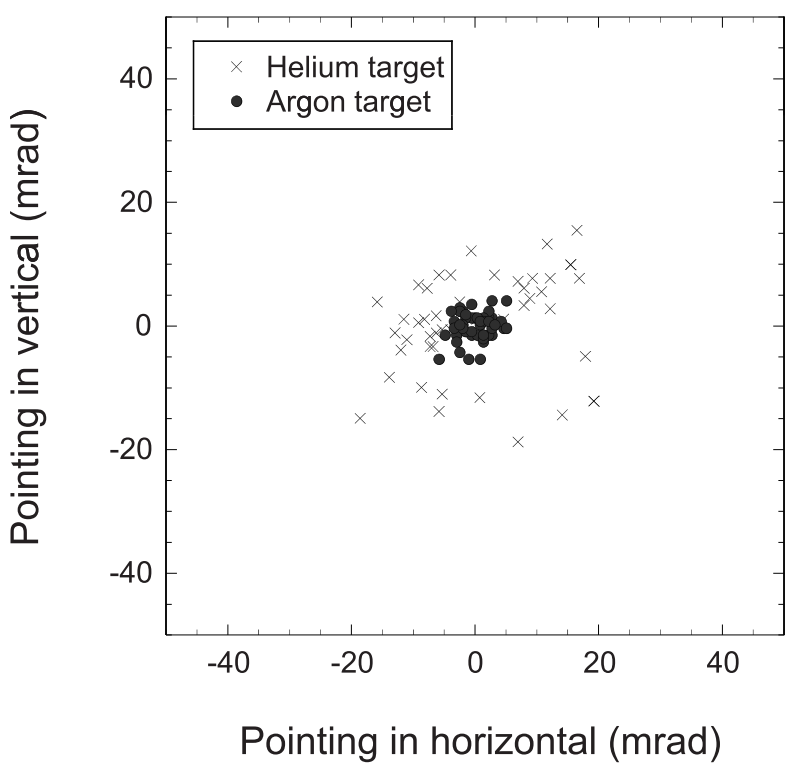

Fig. 3 Beam pointing stability of electron bunch using $\mathrm{He}$ and Ar target. 
(a) Helium

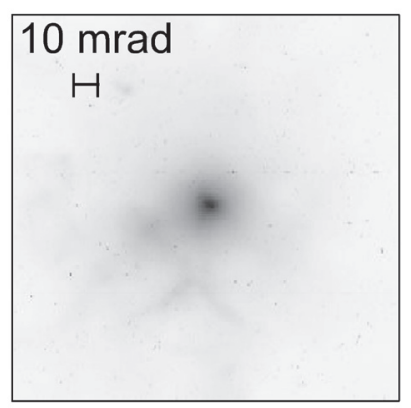

(b) Argon

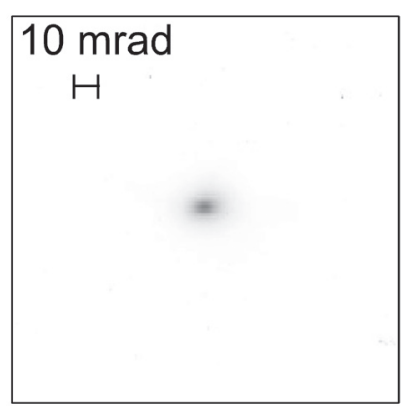

Fig. 4 Spatial beam profile of energetic electrons $(>1 \mathrm{MeV})$

ウェーク場を形成しながら伝搬していく際に副次的に発 生するトムソン散乱 (90度トムソン散乱)のイメージより 評価できる。そのためこの散乱が強く生じる，励起レー ザー光の横断面方向の偏光方向と直交する方向 (本実験 ではgas-jetの上(下)部に相当)に，ガスジェット等の装 置類が収まっている真空容器の上面に観測空を介した顕 微鏡を構成してCCDカメラで観測した。その結果，ア ルゴンでほぼレーザーのレーリー長 $($ 約 $1.3 \mathrm{~mm}$ ) に相当 する, ヘリウムに比べて3倍以上長尺なウェーク場 (約 $1.5 \mathrm{~mm})$ を観測し，上記の導波路形成の考察に妥当な結 果が得られた (Fig. 5)。

他方で加速された電子ビームのエネルギーのピークは アルゴンターゲット $(\sim 8.5 \mathrm{MeV})$ でヘリウムターゲット (〜25 MeV)に比べ1/3近くに低下していることを観測し

(a) Helium
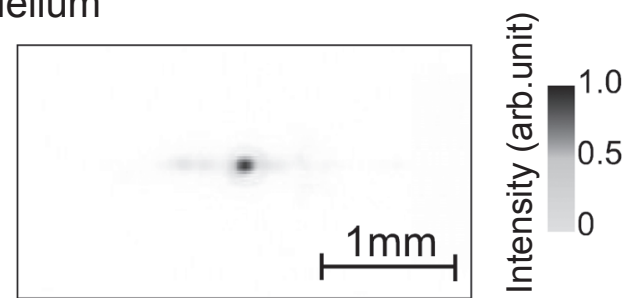

(b) Argon

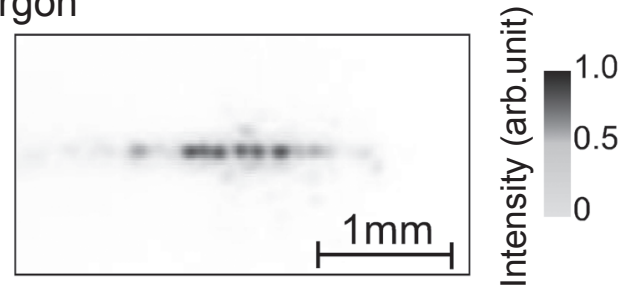

Fig. $590^{\circ}$ Thomson scatter image in (a) He and (b) Ar.
た(Fig. 6)。本実験では，相対論的自己集束 ${ }^{33-35)}$ が発生 するための条件，すなわちメインレーザーパルス幅がプ ラズマ周期に比べ十分に長く，且つレーザーパワーの条 件 ${ }^{35)}\left(P_{\mathrm{c}}=16.2 n_{\mathrm{c}} / n_{\mathrm{e}} \mathrm{GW}\right.$ ，ここで $\mathrm{n}_{\mathrm{c}}$ はレーザーのカットオ フ密度, $\mathrm{n}_{\mathrm{e}}$ はプラズマ電子密度を示す)を満たすため, これによって実効的なレーザー強度の増加が見込まれ る。したがって，アルゴンターゲットでは元々9価程度 だった電離の価数がこの強度の増加によってより多価ま で進展し，その結果実効的なプラズマ電子密度が増加す る。このような追加的な密度増加はプラズマ波の位相速 度の低下に結びつくためエネルギー低下に繋がる。過去 ヘリウムで行った実験とそのメカニズムを考察するため に行ったParticle-in-Cellシミュレーションの結果では, 双方とも30\%程度のプラズマ電子密度の増加に対して 50\%近くのエネルギーの低下が生じることを明らかにし ていた ${ }^{36)}$ が，本実験では丁度相対論的自己収束による
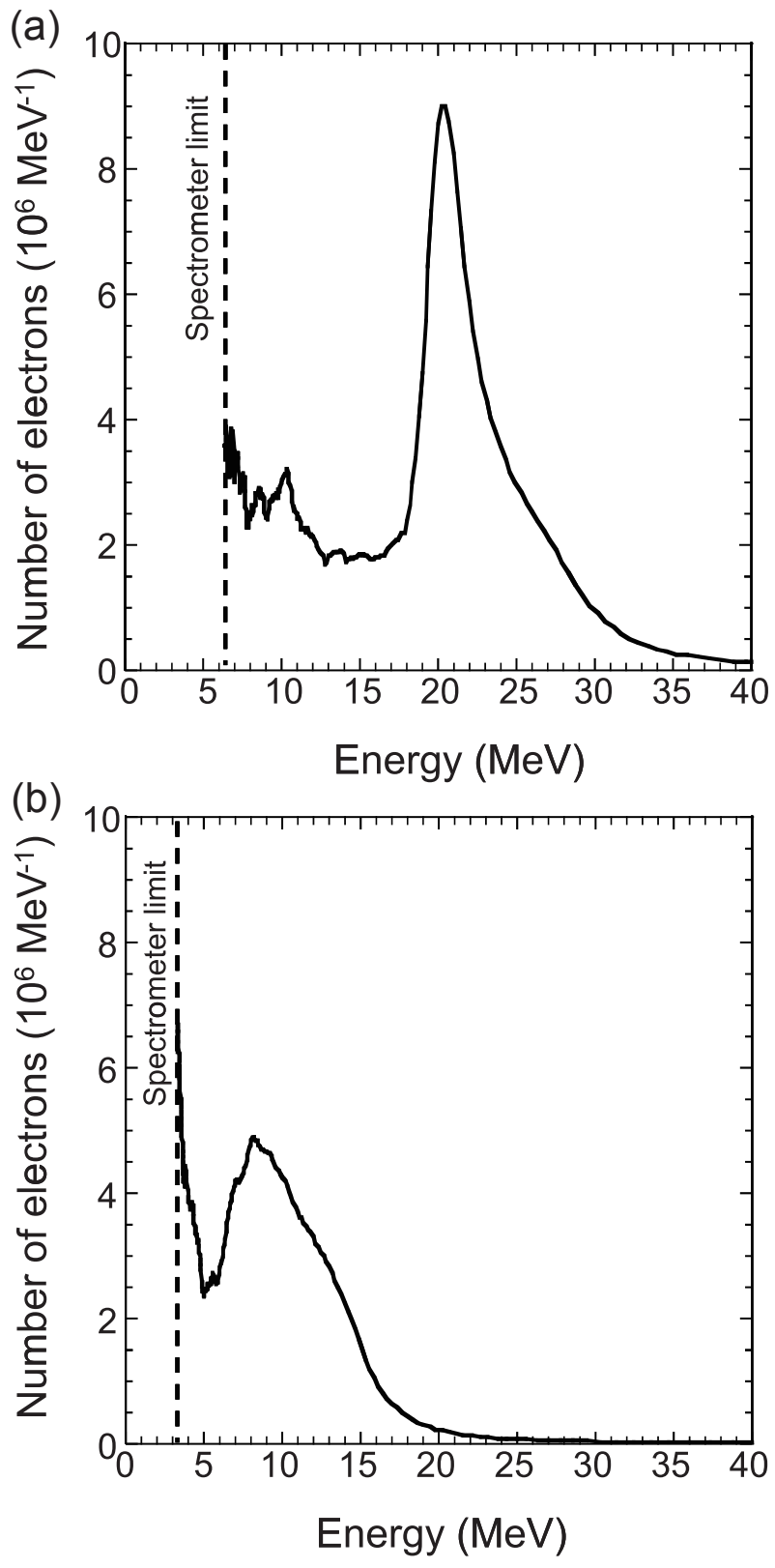

Fig. 6 Typical energy distribution of electron bunch in (a) He and (b) Ar. 
レーザー強度の増加で電離が急速に進展する条件であっ た事から，これと類似したメカニズムでエネルギーの低 下が生じたと考えられる。

これらの実験結果で得られたへリウム，アルゴンそれ ぞれで発生した電子ビームのパラメータの比較をTable 1 に示す。アルゴンターゲットに抽てへリウムと比較し て電子ビームの位置安定性やビーム発散角抑制以外に も，40\%近くだった準単色電子ビームの発現率が80\%を 超える大幅な改善(Fig. 7) とショット毎の電子ビームの 電荷量の安定性向上も確認している.

さて，前述のエネルギーの低下に対しては，上記のメ カニズムによるプラズマ電子密度の追加的な増加量の少 ないガス例えば窒素ガスを選ぶことにより防ぐことが出 来る (Fig. 8)。実際, この後の研究では同じレーザー照 射条件で窒素ターゲットを用いることで, 高エネルギー

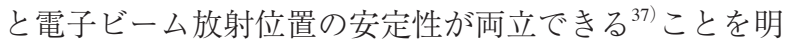
らかにしており，最近の結果では，50 shotの統計でピー クエネルギーでE=33 $\pm 6.6 \mathrm{MeV}($ avg \pm s.d.) (Fig. 9), ビーム位置安定性 $1.1 \mathrm{mrad}(\mathrm{rms})$, ビーム発散角 $6.0 \pm 2.5 \mathrm{mrad}(\mathrm{avg} \pm \mathrm{s} . \mathrm{d} .(\mathrm{FWHM}))$ の結果を得ている. このときの中性ガス密度は $3.5 \times 10^{18} \mathrm{~cm}^{-3}$ である。これ は，窒素で5価までの電離を仮定すると，前述のへリウ ム, アルゴンとほほ同じプラズマ密度であり, プラズマ 波の位相速度によって決まるDephasing limitの約 $40 \mathrm{MeV}$ に近いことから，ガス種の最適化によって効率的な加速 が行われている事を示している。この窒素での結果につ いては, Raoらのグループも同様のレーザー/プラズマ条

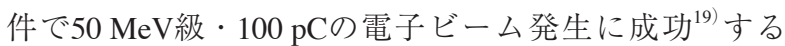

Table 1 Electron beam parameter in $\mathrm{He}$ and Ar.

\begin{tabular}{ccc}
\hline Target & Helium & Argon \\
\hline $\begin{array}{c}\text { Charge (pC/shot) } \\
\text { Pointing stability (mrad) } \\
\text { (root-mean-square(rms)) }\end{array}$ & $19.8 \pm 10.6$ & $9.2 \pm 3.3$ \\
$\begin{array}{c}\text { Beam divergence in full- } \\
\text { width-half-maximum(mrad) } \\
\text { (average (avg) } \pm \text { standard } \\
\text { deviation(s.d.) })\end{array}$ & $29.8 \pm 8.8$ & 2.4 \\
$\begin{array}{c}\text { Peak Energy(MeV) } \\
\text { (avg } \pm \text { s.d.) }\end{array}$ & $24.8 \pm 3.6$ & $8.5 \pm 0.8$ \\
$\begin{array}{c}\text { Reproducebility of quasi- } \\
\text { monoenergetic distribution(\%) }\end{array}$ & 38 & 84 \\
\hline
\end{tabular}

*determined by 50 sequential shots
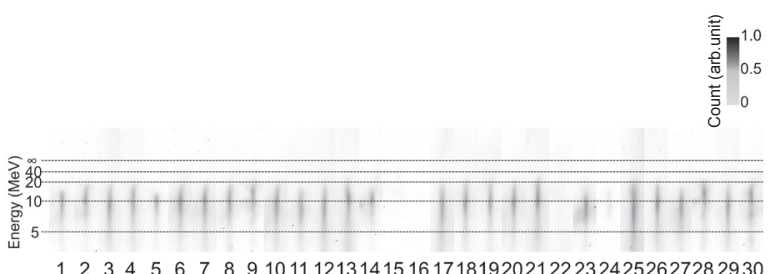

Fig. 7 Images of electron energy distribution at ESM for 30 consecutive shots. The inset numbers show shot numbers.
など類似した結果を得ている。このように，アルゴンの 結果と窒素の結果を総合して考えると, 本手法はビーム の位置安定性や発散角の抑制以外にも，追加的な電離構 造を使いこなすことによってエネルギー制御性も有して いるものと考えられる.

その一方で, 高Zガスの種類によっては逆に電子ビー ム発生を阻害する場合もある。例えば前述と同じレー ザー条件でターゲットをネオンに置き換えた場合，有意 な電子ビーム $(>1 \mathrm{pC}$ for $>1 \mathrm{MeV})$ の発生が認められな かった。この時の中性ガス密度はへリウム，アルゴン双 方で最も発散角の小さな電子ビームを観測したプラズマ 密度 (電子密度) の $4.5 \times 10^{19} \mathrm{~cm}^{-3}$ に相当する $6 \times 10^{18} \mathrm{~cm}^{-3}$ $\left(9 \times 10^{17} \mathrm{~W} / \mathrm{cm}^{2}\right.$ のインのピーク強度を仮定)である. ガス密度の増加は, 相対論効果による凸レンズ効果の増 加につながるため実効的なレーザー強度を増加させると

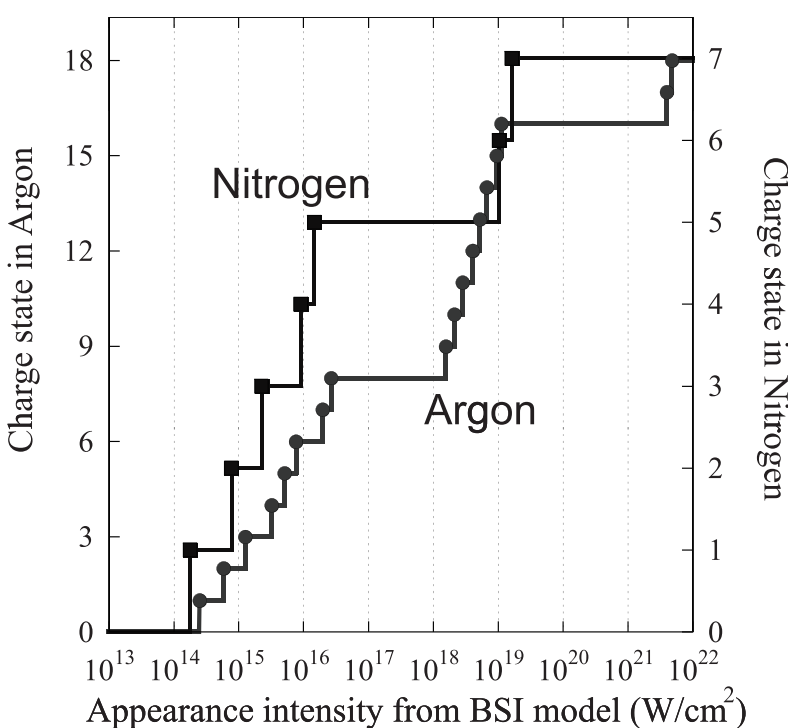

Fig. 8 Charge states in Ar and $\mathrm{N}_{2}$ as a function of laser intensity from BSI model. ${ }^{22)}$

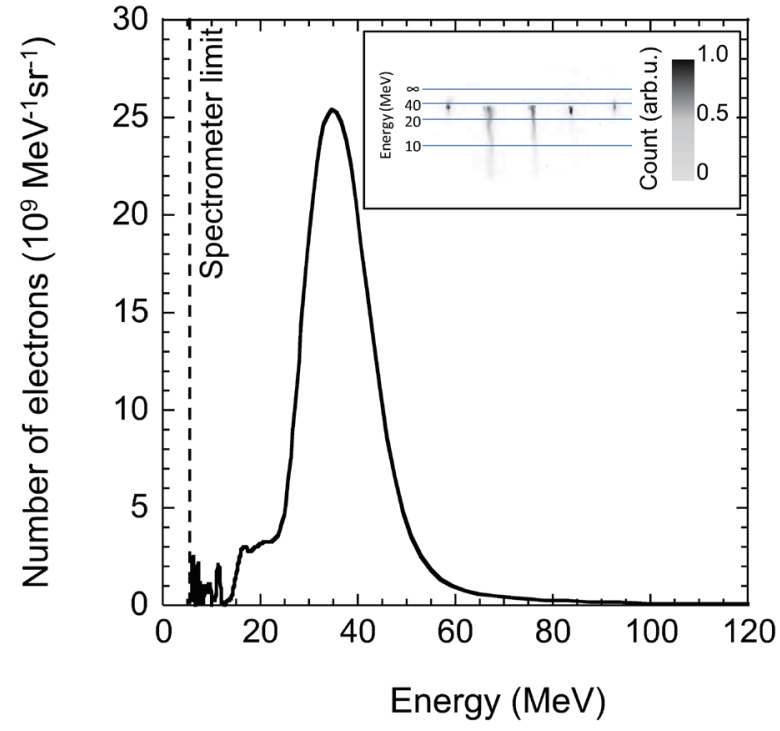

Fig. 9 Typical energy distributions at nitrogen target. The insets show energy resolved electron images for 5 consecutive shots. 
ともに，プラズマ波の位相速度の低下による電子ビーム 発生の条件の緩和に繋がる ${ }^{38)}$. そのため, さらに中性ガ 久密度を $5 \times 10^{19} \mathrm{~cm}^{-3}$ まで走査的に増加させた。しかし ながら,この走査でも有意 $(>1 \mathrm{MeV},>1 \mathrm{pC})$ な電子 ビームの発生は認められなかった。さらに，90度卜ムy ン散乱計測においても有意な散乱光を観測せずウェーク 場の形成に至っていないことも分かった。この結果をさ らに調べるために，メインレーザーに対し90度方向から の光プローブ(パルス幅 $40 \mathrm{fs}$ ) によるアルゴン拉よびネオ ンそれぞれの励起レーザー光の伝搬の比較を行った (Fig. 10)。ここで設定した中性ガス密度は $5 \times 10^{18} \mathrm{~cm}^{-3}$ および $6 \times 10^{18} \mathrm{~cm}^{-3}$ であり, $9 \times 10^{17} \mathrm{~W} / \mathrm{cm}^{2}$ の強度のレー ザー照射で推測される電離価数から換算して電子密度は 双方ともほぼ $5 \times 10^{19} \mathrm{~cm}^{-3}$ に相当する。この結果から, アルゴンで生じているレーザーチャネルの構造がネオン では強力に抑制され，電子ビームの発生を阻害している 原因であることが分かった．Fig. 11にBSIモデルに基づ くアルゴン, 窒素抢よびネオンの電離度のレーザー強度 依存性の比較を示す．特に光導波路をもたらす第1イオ ン化ポテンシャルについて着目するとアルゴンと窒素は ほぼ同じ第1イオン化ポテンシャル（それぞれ $E_{\mathrm{i} A \mathrm{r}}=15.7 \mathrm{eV}$, $\left.E_{\mathrm{i}, \mathrm{N} 2}=14.5 \mathrm{eV}\right)$ に対し，ネオンは高い第1イオン化ポテン シャル $\left(E_{\mathrm{i}, \mathrm{Ne}}=21.6 \mathrm{eV}\right)$ を有する。これは，カスケード電 離のしきい值 ${ }^{31}$ から考察すると, 光ガイドを誘起するよ

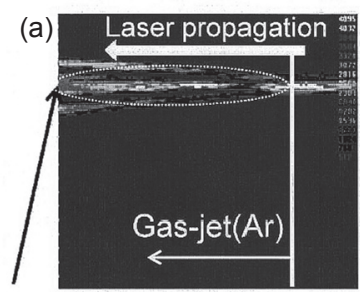

Laser channel

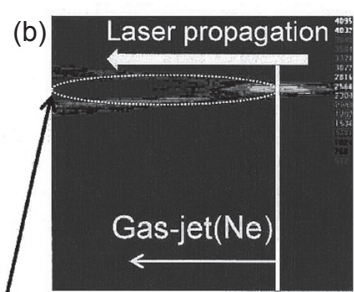

Diffused laser beam
Fig. $1090^{\circ}$ optical probe image in (a) Ar and (b) Ne.

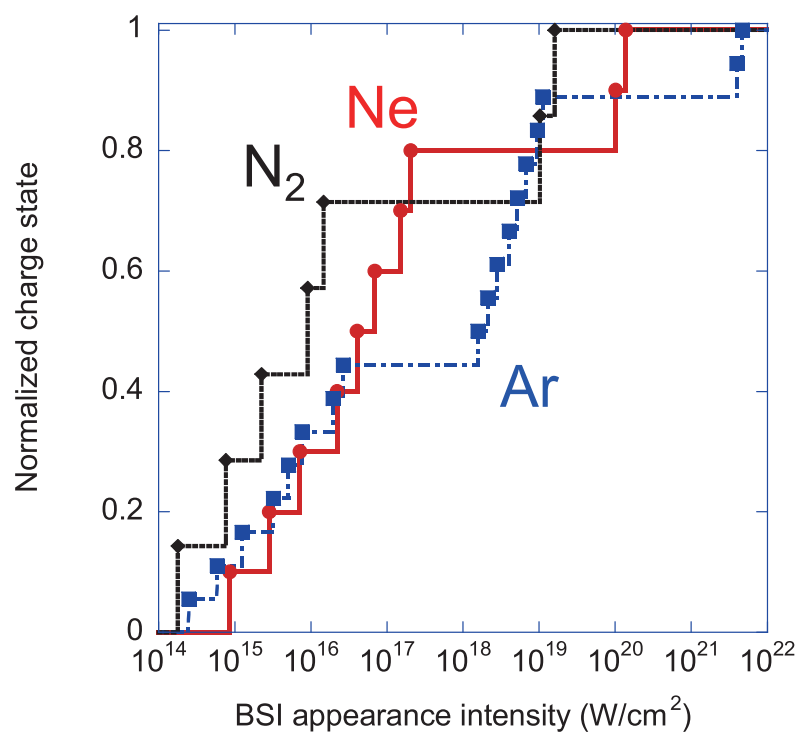

Fig. 11 Normalized charge state as a function of laser intensity from BSI model. ${ }^{22}$
うな光導波路の形成がネオンでは困難であることを示 す。さらにこれに $10^{17} \mathrm{~W} / \mathrm{cm}^{2}$ を超える強度まで電離構造 が延びている事も重なるため，凹面レンズと同等の効果 でレーザー光の収束を妨げ，結果的に電子ビームの発生 を妨げていると考えられる。いずれにしても、レーザー 条件に応じた適切なガスの選択が必要な事は明らかであ る。

\section{4. まとめ}

レーザー加速電子ビーム制御手法の一つとして, High-Zガスターゲットを用いた制御手法について紹介し た．High-Zガスターゲットによる電子ビームの制御の手 法は他の手法に比ベシンプルであり，また制御性と別の メリットとしてHigh-Zガスの多価の電離を利用すること から，供給するガス量を減らすことができるため，高繰 り返し動作に扔いても有利である。今後，より実用に供 する電子ビーム源の実現のため, ビームの利用研究との 連携が不可欠であり，他の制御手法との併用やレーザー 装置の改良などの研究開発と並行する形で展開すること が重要になっていくと考えられる。

\section{謝 辞}

本研究の一部は, 基盤研究 (C) (No.21540414)の支援 を受け研究を行いました。また本研究は、日本原子力研 究開発機構近藤公伯, 神門正城, 小瀧秀行, 林 由紀雄，西内 満美子，アレクサンダーピロジコフ， 小倉浩一, 杉山博則, セルゲイブラノフ, 大道博行, 大阪大学 水田好雄, 田中和夫，西村博明諸氏との共同 研究の成果であり，ここに感謝いたします。

\section{参考文献}

1) E. Esarey, R. F. Hubbard, W. P. Leemans, A. Ting, and P. Sprangle: Phys. Rev. Lett. 79 (1997) 2682.

2) H. Kotaki, S. Masuda, M. Kando, J. K. Koga, and K. Nakajima: Phys. Plasmas 9 (2002) 1392.

3) J. Faure, C. Rechatin, A. Norlin, A. Lifschifz, Y. Glinec, and V. Malka: Nature 444 (2006) 737.

4) H. Kotaki, I. Daito, M. Kando, Y. Hayashi, K. Kawase, T. Kameshima, Y. Fukuda, T. Homma, J. Ma, L.-M. Chen, et al.: Phys. Rev. Lett. 103 (2009) 194803.

5) C. Rechatin, X. Davoine, A. Lifschitz, A. Ben Ismail, J. Lim, E. Lefebvre, J. Faure, and V. Malka: Phys. Rev. Lett. 103 (2009) 194804.

6) T. Hosokai, K. Kinoshita, A. Zhidkov, A. Maekawa, A. Yamazaki, and M. Uesaka: Phys. Rev. Lett. 97 (2006) 075004.

7) 細貝知直：プラズマ・核融合学会誌 86 (2010) 143.

8) S. Bulanov, N. Naumova, F. Pegoraro, and J. Sakai: Phys. Rev. E 58 (1998) R5257.

9) C. G. R. Geddes, K. Nakamura, G. R. Plateau, Cs. Toth, E. Cormier-Michel, E. Esarey, C. B. Schroeder, J. R. Cary, and W. P. Leemans: Phys. Rev. Lett. 100 (2008) 215004.

10) S. P. D. Mangles, A. G. R. Thomas, M. C. Kaluza, O. Lundh, F. Lindau, A. Persson, Z. Najmudin, C.-G. Wahlström, C. D. Murphy, C. Kamperidis, K. L. Lancaster, E. Divall, and K. Krushelnick: Plasma Phys. Control Fusion 48 (2006) B83.

11) E. Miura and S. Masuda: Appl. Phys. Express 2 (2009) 126003.

12) H. Kotaki, M. Kando, I. Daito, T. Kameshima, K. Kawase, L. Chen, Y. Fukuda, J. K. Koga, H. Kiriyama, S. Kondo, et al.: Jpn. 
J. Appl. Phys. 50 (2011) 066401.

13) E. Miura, K. Koyama, S. Kato, N. Saito, M. Adachi, Y. Kawada, T. Nakamura, and M. Tanimoto: Appl. Phys. Lett. 86 (2005) 251501.

14) M. Mori, K. Kondo, Y. Mizuta, M. Kando, H. Kotaki, M. Nishiuchi, M. Kado, A. S. Pirozhkov, K. Ogura, H. Sugiyama, et al.: Phys. Rev. ST Accel. Beams 12 (2009) 082801.

15) A. Pak, K. A. Marsh, S. F. Martins, W. Lu, W. B. Mori, and C. Joshi: Phys. Rev. Lett. 104 (2010) 025003.

16) C. McGuffey, A. G. R. Thomas, W. Schumaker, T. Matsuoka, V. Chvykov, F. J. Dollar, G. Kalintchenko, V. Yanovsky, A. Maksimchuk, K. Krushelnick, et al.: Phys. Rev. Lett. 104 (2010) 025004.

17) J. S. Liu, C. Q. Xia, W. T. Wang, H. Y. Lu, Ch. Wang, A. H. Deng, W. T. Li, H. Zhang, X. Y. Liang, Y. X. Leng, et al.: Phys. Rev. Lett. 107 (2011) 035001.

18) B. B. Pollock, C. E. Clayton, J. E. Ralph, F. Albert, A. Davidson, L. Divol, C. Filip, S. H. Glenzer, K. Herpoldt, W. Lu, et al.: Phys. Rev. Lett. 107 (2011) 045001.

19) B. S. Rao, J. A. Chakera, P. A. Naik, M. Kumar, and P. D. Gupta: Phys. Plasmas 18 (2011) 093104.

20) L. V. Keldysh: Zh. Eksp. Teor. Fiz. 47 (1964) 1945 [Sov. Phys. JETP 20 (1965) 1307].

21) M. V. Ammosov, N. B. Delone, and V. P. Kraĭnov: Zh. Eksp. Teor. Fiz. 91 (1986) 2008 [Sov. Phys. JETP 64 (1986) 1191].

22) S. Augst, D. Strickland, D. D. Meyerhofer, S. L. Chin, and J. H. Eberly: Phys. Rev. Lett. 63 (1989) 2212.

23) T. Tajima and J. M. Dawson: Phys. Rev. Lett. 43 (1979) 267.

24) E. Oz, S. Deng, T. Katsouleas, P. Muggli, C. D. Barnes, I. Blumenfeld, F. J. Decker, P. Emma, M. J. Hogan, R. Ischebeck, et al.: Phys. Rev. Lett. 98 (2007) 084801.

25) S. P. Hatchett, C.G. Brown, T. E. Cowan, E. A. Henry, J. S.
Johnson, M. H. Key, J. A. Koch, A. B. Langdon, B. F. Lasinski, R. W. Lee, et al.: Phys. Plasmas 7 (2000) 2076.

26) M. Kaluza, J. Schreiber, M. I. K. Santala, G. D. Tsakiris, K. Eidmann, J. Meyer-ter-Vehn, and K. J. Witte: Phys. Rev. Lett. 93 (2004) 045003.

27）千徳靖彦, 兒玉了祐：プラズマ・核融合学会誌 81 (2005) 145.

28) M. Mori, A. Yogo, H. Kiriyama, M. Nishiuchi, K. Ogura, S. Orimo, J. Ma, A. Sagisaka, S. Kanazawa, S. Kondo, et al.: IEEE Trans. Plasma Sci. 36 (2008) 1872.

29) D. Neely, P. Foster, A. Robinson, F. Lindau, O. Lundh, A. Persson, C.-G. Wahlstrom, and P. McKenna: Appl. Phys. Lett. 89 (2006) 021502.

30) D. H. Gili and A. A. Dougal: Phys. Rev. Lett. 15 (1965) 845.

31) 山中 龍彦：プラズマ・核融合学会誌 69 (1993) 656.

32) P. Sprangle and E. Esarey: Phys. Fluids B 4 (1992) 2241.

$33)$ G.-Z. Sun, E. Ott, Y. C. Lee, and P. Guzdar: Phys. Fluids 30 (1987) 526.

34) P. Sprangle, E. Esarey, and A. Ting: Phys. Rev. A 41 (1990) 4463.

35) A. B. Borisov, A. V. Borovskiy, O. B. Shiryaev, V. V. Korobkin, A. M. Prokhorov, J. C. Solem, T. S. Luk, K. Boyer, and C. K. Rhodes: Phys. Rev. A 45 (1992) 5830.

36) M. Mori, M. Kando, I. Daito, H. Kotaki, Y. Hayashi, A. Yamazaki, K. Ogura, A. Sagisaka, J. Koga, K. Nakajima, and H. Daido: Phys. Lett. A 356 (2006) 146.

37) M. Mori, K. Kondo, H. Kotaki, Y. Hayashi, K. Kawase, S.V. Bulanov, K. Ogura, A. S. Pirozhkov, K. Kondo, A. Sugiyama, et al.: Proc. IPAC'10 (2010) THPEC003.

38) S. Masuda, E. Miura, K. Koyama, S. Kato, M. Adachi, T. Watanabe, K. Torii, and M. Tanimoto: Phys. Plasmas 14 (2007) 023103.

\section{相対論的自己収束 (relativistic self-focusing)}

高強度レーザーとプラズマとの相互作用で生じる現象 の1つ. プラズマ中の屈折率は, 電子の質量をパラメー タの一つとするプラズマ周波数に依存する。したがっ て, 一様分布のプラズマ中に高強度レーザー光を入射す ると, レーザー光の強度分布に応じた屈折率分布が生じ る.これはガウス様ビームの場合, 一種の屈折率分布型 の集光レンズとして働くためレーザー光を集光させる. さらにこの集光はレーザー強度の増加をもたらすため,
一層強力な集光レンズの形成とレーザー強度の増加を生 じさせる。これらの一連の過程が連鎖的に繰り返される ことで, 結果的にスポット径が小さく強度の非常に高い レーザー光チャネル (伝送路) が形成される. 解析的考察 から,この現象の発現には概ね16.2 $\left(n_{\mathrm{e}} / n_{\mathrm{c}}\right)(\mathrm{GW})\left(n_{\mathrm{e}}: 7^{\circ}\right.$ ラズマ密度, $n_{\mathrm{c}}$ : レーザーのカットオフ密度)のレー ザー出力 (レーザー強度では無い)を必要とする(十分条 件で無い事にも注意). 